\title{
Contribution of thermal imaging to fertigation in soilless culture
}

\author{
Isidro Morales · Juan E. Álvaro $\cdot$ Miguel Urrestarazu
}

Received: 10 August 2013/Accepted: 5 November 2013/Published online: 11 December 2013

(C) The Author(s) 2013. This article is published with open access at Springerlink.com

\begin{abstract}
Thermography is a tool used in many scientific disciplines, including agriculture. This paper describes the application of thermography as a rapid diagnostic method of adequate watering. Two experiments were conducted. In experiment 1, Philodendron erubescens and Anthurium andraeum were transplanted to pots in a greenhouse in Almeria (Spain). The vegetative growth parameters of these plants were measured. In experiment 2 , two areas of vegetative cover were established on green walls: one with a combination of aromatic plants and another with ornamental indoor plants. The thermographic images were recorded using a compact infrared camera, which had a spectral infrared range of 7.3-13 $\mu \mathrm{m}$, microbolometer of $320 \times 240$ pixels, and the resolution was $0.01{ }^{\circ} \mathrm{C}$ at $30{ }^{\circ} \mathrm{C}$. Three irrigation treatments were applied in both experiments, consisting of a control treatment (CT), a deficit irrigation [1/3 less volume, deficient irrigation (DI)] treatment, and an excess irrigation [1/3 greater volume, excess irrigation (EI)] treatment. In both experiments, the sample temperatures were recorded by thermography for each irrigation treatment. In experiment 1 , the vegetative growth parameters were greater under CT than under DI or EI. The data of the reference thermographs over the leaves of the potted plants were significantly correlated with the superior growth parameters under the optimal irrigation treatment. A continuous vegetative canopy was formed on both of the green walls in experiment 2 , and the average temperatures were correlated with the irrigation treatments in this
\end{abstract}

I. Morales · J. E. Álvaro · M. Urrestarazu ( $\square)$ Department of Agronomy (Departamento de Agronomía), University of Almeria (Universidad de Almería), La Cañada de San Urbano s/n, 04120 Almería, Spain e-mail: mgavilan@ual.es experiment. The temperatures reflected in the reference thermographs allowed for the determination of the most appropriate irrigation treatment. These results suggest that thermography can be a useful method to provide an early diagnosis of water stress in potted plants and green walls.

Keywords Green wall - Thermography ·

Thermometry - Sensor techniques - Fertigation .

Non-invasive monitoring

\section{Introduction}

Infrared thermography is used in many fields of science [1] and technology [2], including agriculture and horticulture [3-8] and plant physiology $[9,10]$. The technology can be utilized specifically to monitor the efficiency of water resource use for both field applications [11] and potted plants in a soilless culture $[12,13]$. The leaf temperature of plants is the result of both external and internal (physiological) factors. A correlation exists between leaf temperature and water status, as water is the primary source of infrared absorption in plant tissue [14]. The relationship between leaf transpiration and crop water stress is well-established [15]. Transpiration is regulated by a stomatal feedback control mechanism, which is in turn influenced by water deficits $[12,16]$; due to the negative correlation between transpiration rate and leaf temperature, digital infrared thermography allows for the non-invasive monitoring and indirect visualization of potential stress. Several previous studies have employed digital infrared thermography in horticulture for disease control [17-22], but relatively few studies have proposed the use of thermography for the early diagnosis of issues with a fertigation distribution system [12], water stress [8], or salt tolerance in crops $[13,23]$. 
A real need exists for sensitive, easy, economic, and robust techniques for the detection of water and other plant stresses, especially before these stresses manifest as crop damage.

The present work investigates the potential of infrared thermography as a tool for fertigation. The study evaluates the capability of infrared thermography as an early, rapid, and simple method for diagnosing the volume of fertigation by soilless culture under pot and green wall conditions.

\section{Materials and methods}

Experiment 1

\section{Crop}

The experiment started on 25 February 2013 in a greenhouse at the University of Almeria (Almeria, Spain). Seedlings (65 days old) of philodendron (Philodendron erubescens K. Koch and Augustin cv. Imperial red) and anthurium (Anthurium andraeanum Linden Ex André) were transplanted to $0.5-\mathrm{L}$ pots filled with a mixture of peat and coir fiber (1:2 vol:vol). Each pot (crop unit) was fertigated with a standard nutrient solution [24] for 90 days to anthurium and syngonium, using a self-compensating, non-draining dripper with a flow rate of either 2,3 , or $4 \mathrm{~L} \mathrm{~h}^{-1}$. For all treatments, new fertigation was supplied whenever a pot had absorbed between 10 and $20 \%$ of the easily available water, as determined from the control treatment $(\mathrm{CT})[25,26]$. The flow rate of the CT was $3 \mathrm{~L} \mathrm{~h}^{-1}$, while the flow rate for the deficient irrigation (DI) treatment was $2 \mathrm{~L} \mathrm{~h}^{-1}$, with a fertigation volume $1 / 3$ less than the CT. The flow rate for the excess irrigation (EI) treatment was $4 \mathrm{~L} \mathrm{~h}^{-1}$, with a fertigation volume $1 / 3$ more than the CT.

\section{Thermometric measures}

The thermographic images were recorded using a compact infrared camera, the Fluke ${ }^{\circledR}$ Ti32 Thermal Imaging Scanner (Janesville, WI, USA), which has a spectral infrared range of $7.3-13 \mu \mathrm{m}$, a temperature range of -40 to $+600{ }^{\circ} \mathrm{C}$, and an accuracy of $\pm 2 \%$. The detector was a focal plane array (an uncooled microbolometer of $320 \times 240$ pixels), and the field of view was $20^{\circ}$, with a minimal focus distance of $0.3 \mathrm{~m}$. The resolution was $0.01{ }^{\circ} \mathrm{C}$ at $30^{\circ} \mathrm{C}$. The emissivity was 0.95 . The thermal measurements were obtained at midday according to the methods of Inagaki and Nachit [5] and Fernández-Bregón et al. [12]. The measurements were taken from leaves on half of the stem at a constant, predetermined orientation and position in the plant (Fig. 1d) from an approximately $3-5 \mathrm{~cm}^{2}$ area, in agreement with the criteria of Urrestarazu [13] (Fig. 1b). The lens was perpendicular to leave surface.

A thermographic image was taken from each plant in each of the three treatments at the same time (Figs. 1, 2, 3, and 4).
Fig. 1 a is a thermograph of the three irrigation volumes, where CT is the control, DI has $1 / 3$ less irrigation, and EI has $1 / 3$ more irrigation. Dripper irrigation occurs at flow rates of 2, 3, and $4 \mathrm{~L} \mathrm{~h}^{-1}$, respectively, in each pot. b Thermographic measurement of the average (Avg), minimum (Min), and maximum (Max) temperatures of a representative leaf area. c Thermographic data of a pot with the same irrigation volume. d is the reference photograph
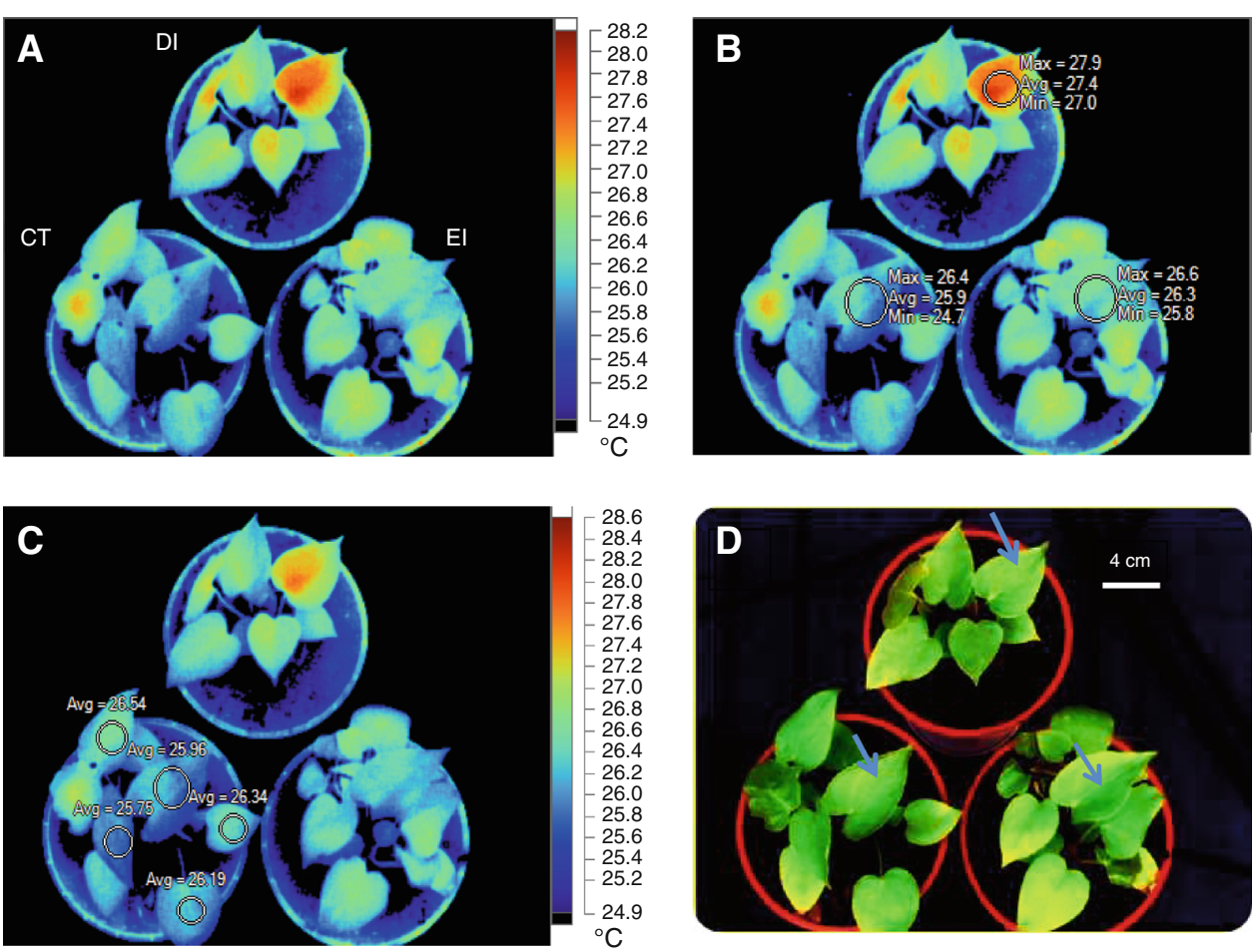

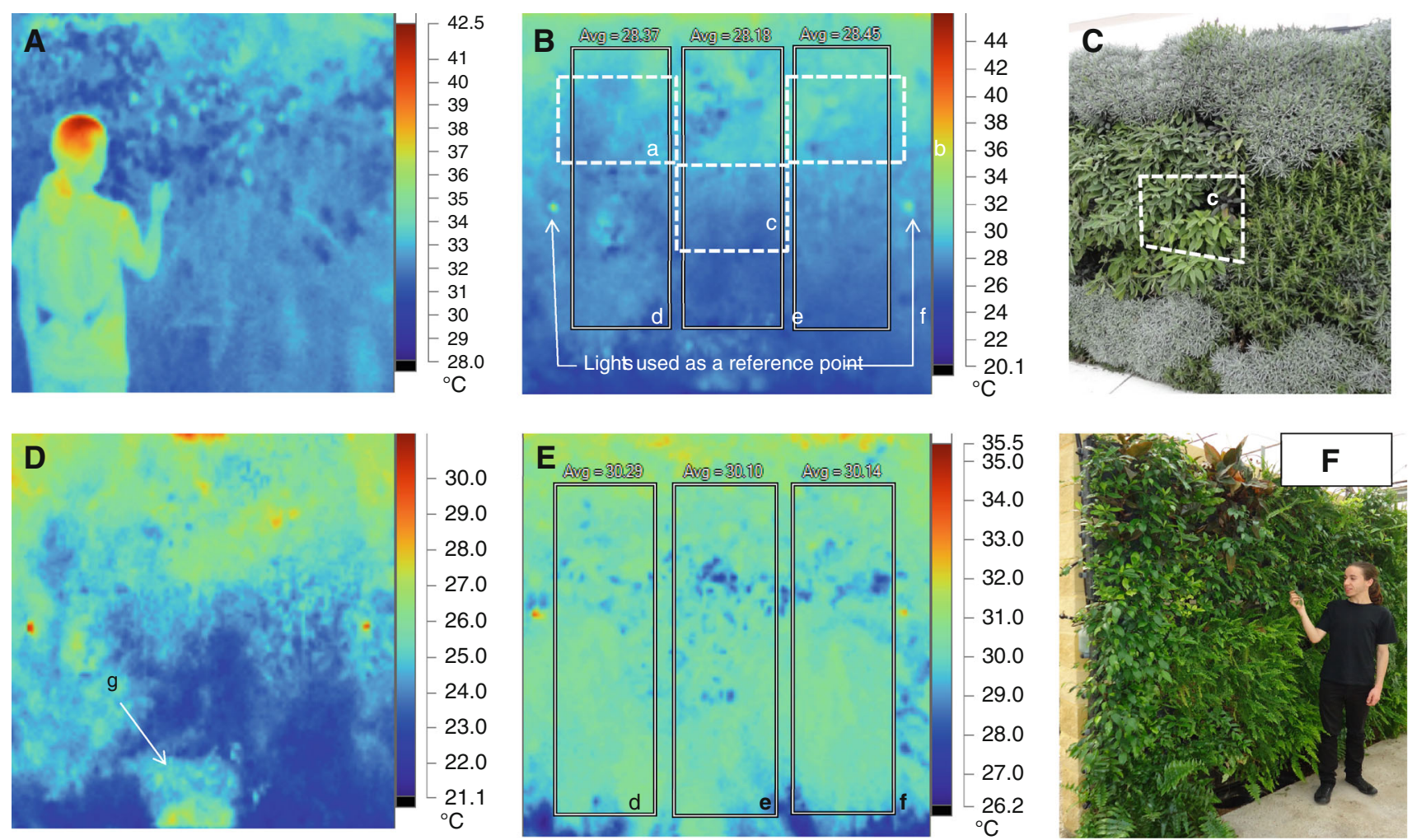

Fig. $2 \mathbf{a}$ is a reference thermograph, $\mathbf{b}$ is a thermograph of a vegetative wall of aromatic plants, and $\mathbf{c}$ is a photograph of a wall of aromatic plants. $\mathbf{a}, \mathbf{b}$, and $\mathbf{c}$ are the spaces that occupy three of the cultivated modular units covering the vegetative wall; $\mathbf{d}$, e, and f are the areas used to measure thermograph temperatures for each

\section{Thermometric analysis}

The camera used in this study is supported by the software package SmartView 3.2 ${ }^{\mathrm{TM}}$ Researcher Pro (Fluke Thermography, Plymouth, MN, USA) and a Microsoft Windows XP platform, which offers analytical functions including point temperatures, profiles, histograms, isotherms, and the determination of the maximum temperature in the image (Figs. 1, 2, 3, and 4).

\section{Growth parameters}

Ninety days after the transplant, the plants from each treatment and repetition were divided into roots, stems, and leaves. After the measurement of the fresh mass for each portion, the dry mass of the roots, stems, and leaves were determined after drying at $85{ }^{\circ} \mathrm{C}$ until reaching a constant mass (Table 1).

\section{Experimental design and statistical analysis}

Four replicates were used for each measurement and treatment. The experiment was conducted using a completely treatment (2,3 and $4 \mathrm{~L} \mathrm{~h}^{-1}$ drippers). $\mathbf{d}$ is a reference thermograph where irrigation was stopped for 3 days in one cultivated modular unit, bottom center (g). The numbers represent the average temperature of the respective boxes. $\mathbf{e}$ is a thermograph and $\mathbf{f}$ is a reference photograph of a vegetative wall of ornamental indoor plants

randomized design with eight pots in replicates for each treatment.

A Tukey's multiple range test at $P \leq 0.05$ was used to differentiate the means. The experimental design and data analysis were based on the procedure described by Little and Hills [27]. A Statgraphics R_Plus 5.0 statistical package was used to process the data [28].

\section{Experiment 2}

A second experiment conducted on a green wall under similar conditions in relation to thermal measurement system and statistical processing of the data as experiment 1 . The experiment was conducted at the University of Almeria (Almeria, Spain). A wall $2.5 \mathrm{~m}$ high and $3.5 \mathrm{~m}$ long was built with concrete blocks. Each block was made of precast concrete and measured $200 \mathrm{~mm}$ high by $190 \mathrm{~mm}$ wide by $400 \mathrm{~mm}$ long.

\section{Green wall}

Two types of vegetative cover were established on the concrete block wall: an aromatic plant cover on the south 

corresponding to 2,3 , and $4 \mathrm{~L} \mathrm{~h}^{-1}$ irrigation flow rates in Philodendron plants; top, left, and right, respectively, in philodendron and syngonium. Avg: Average temperature
Fig. 3 Thermographs

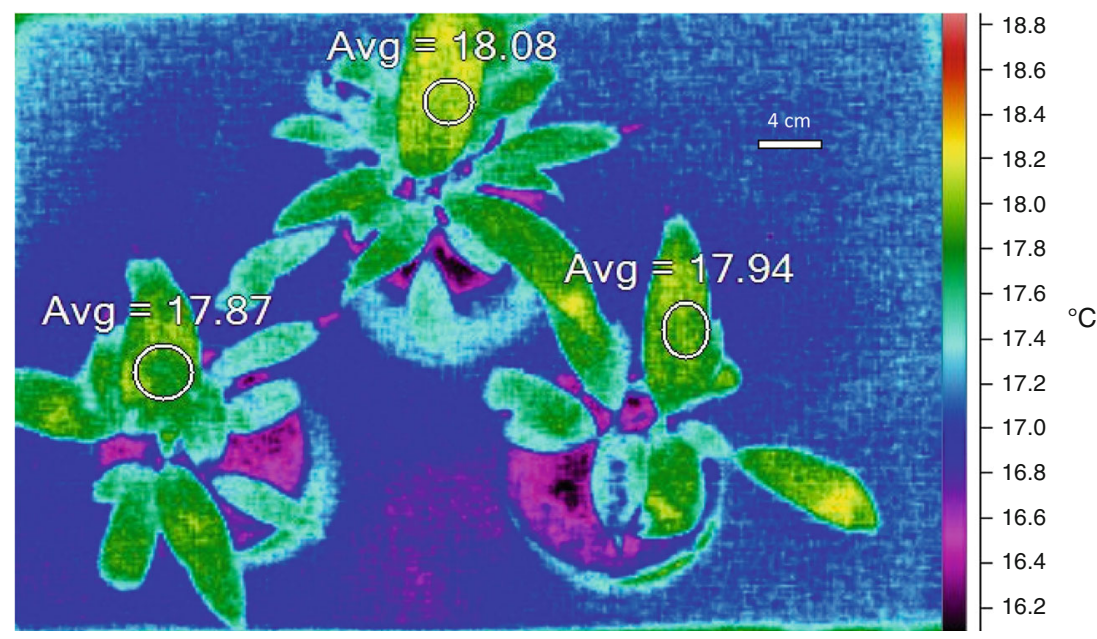

Fig. 4 Relationship between fertigation volumetric flow rate $\left(\mathrm{L} \mathrm{h}^{-1}\right)$ and temperature decrease recorded by thermography. $\mathbf{a}$ is the leaf temperatures of potted Philodendron, $\mathbf{b}$ is the leaf temperatures of potted Anthurium, $\mathbf{c}$ is the vegetative wall of aromatic plants, and $\mathbf{d}$ is the vegetative wall of ornamental indoor plants
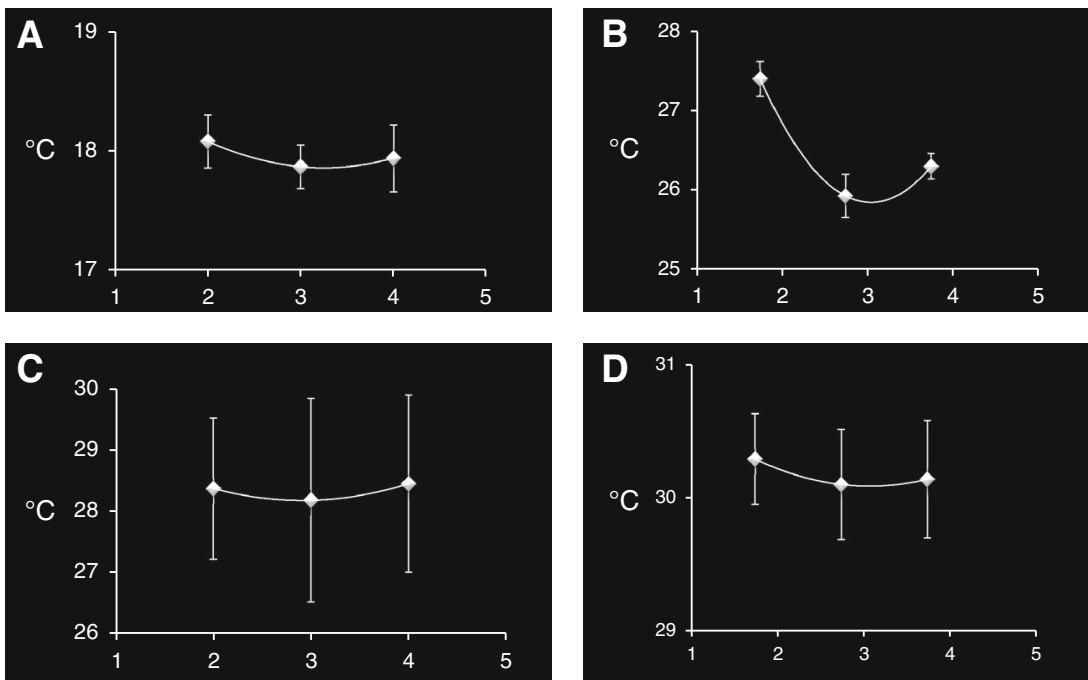

face and an indoor ornamental plant cover on the north face. The covering consisted of modular vegetative units (CMU) measuring $600 \mathrm{~mm}$ long, $400 \mathrm{~mm}$ high, and $100 \mathrm{~mm}$ wide that were fastened to the concrete wall by metal anchors, as in the methods of Urrestarazu and Burés [29] (Fig. 2).

This experiment was conducted according to FernándezBregón et al. [30]. The cultivated CMUs consisted of a combination of six or ten species of aromatic and indoor plants, respectively.

Indoor plants:

- P. erubescens K.Koch and Augustin cv. Imperial red

- Ficus benjamina L. cv. Exotica

- Nephrolepis cordata Hort.

- Nephrolepis cordifolia (L.) C. Prel cv. Duffii

- Nephrolepis biserrata (Sw.) Schott. cv. Macho

- Nephrolepis exaltata (L.) Schott cv. Montana

- Nephrolepis exaltata (L.) Schott cv. Ariana

- Nephrolepis exaltata (L.) Schott cv. Teddy Junior

- Dryopteris erythrosora (D. C. Eaton) Kuntze
- Syngonium podophyllum Schott cv. Robusta

Aromatic plants:

- Helichrysum thianschanicum L.

- Salvia officinalis L.

- Lavandula angustifolia Mill.

- Lavandula stoechas L.

- Rosmarinus officinalis L.

- Thymus vulgaris L.

The plants were distributed in the CMU based on esthetic criteria; when the plants were fully developed, the plant cover was continuous, and it was not possible to identify the specific position of each CMU (Fig. 2c). Therefore, when considering an area larger than that of a CMU, the analysis included several of the species, as seen in Fig. 2b, c.

The CMUs were grown in a greenhouse and transported to the test location for installation on the wall. These plants provided $100 \%$ CMU coverage and an average canopy height of $250 \mathrm{~mm}$. The CMUs were allowed to acclimate in 
Table 1 Parámetros de crecimiento $\left(\mathrm{g}_{\text {plant }}{ }^{-1}\right.$ ) en función de régimen de riego

\begin{tabular}{|c|c|c|c|c|c|c|c|c|c|c|c|}
\hline \multirow[t]{2}{*}{ Plant } & \multirow[t]{2}{*}{ Treatment } & \multicolumn{5}{|c|}{ Fresh mass } & \multicolumn{5}{|c|}{ Dry mass } \\
\hline & & Leaf & Stem & Shoot & Root & Total & Leaf & Stem & Shoot & Root & Total \\
\hline \multirow[t]{3}{*}{ Philodendron } & DI & $7.95 \mathrm{~b}$ & $6.93 \mathrm{c}$ & $14.39 \mathrm{~b}$ & $10.92 \mathrm{c}$ & $25.31 \mathrm{c}$ & $2.67 \mathrm{~b}$ & $2.47 \mathrm{a}$ & $5.04 \mathrm{c}$ & $1.18 \mathrm{~b}$ & $6.22 \mathrm{c}$ \\
\hline & TT & $10.79 \mathrm{a}$ & $9.67 \mathrm{~b}$ & $20.46 \mathrm{a}$ & $12.75 \mathrm{~b}$ & $33.21 \mathrm{~b}$ & $3.41 \mathrm{a}$ & $2.48 \mathrm{a}$ & $5.89 \mathrm{~b}$ & $1.36 \mathrm{ab}$ & $7.25 \mathrm{~b}$ \\
\hline & EI & $11.14 \mathrm{a}$ & $10.67 \mathrm{a}$ & $21.81 \mathrm{a}$ & $15.63 \mathrm{a}$ & $37.44 \mathrm{a}$ & $3.57 \mathrm{a}$ & $3.17 \mathrm{~b}$ & $6.73 \mathrm{a}$ & $1.63 \mathrm{a}$ & $8.36 \mathrm{a}$ \\
\hline \multirow[t]{3}{*}{ Anthurium } & DI & $6.50 \mathrm{~b}$ & $6.82 \mathrm{a}$ & $13.32 \mathrm{~b}$ & $13.67 \mathrm{a}$ & $26.99 \mathrm{a}$ & $1.22 \mathrm{~b}$ & $0.93 \mathrm{a}$ & $2.10 \mathrm{~b}$ & $1.15 \mathrm{a}$ & $3.25 \mathrm{~b}$ \\
\hline & TT & $7.14 \mathrm{a}$ & $6.92 \mathrm{a}$ & $14.06 \mathrm{a}$ & $12.86 \mathrm{a}$ & $26.92 \mathrm{a}$ & $1.28 \mathrm{~b}$ & $1.03 \mathrm{a}$ & $2.44 \mathrm{a}$ & $1.12 \mathrm{a}$ & $3.56 \mathrm{a}$ \\
\hline & EI & $7.31 \mathrm{a}$ & $6.57 \mathrm{a}$ & $13.88 \mathrm{ab}$ & $12.76 \mathrm{a}$ & $26.64 \mathrm{~b}$ & $1.43 \mathrm{a}$ & $1.13 \mathrm{a}$ & $2.57 \mathrm{a}$ & $1.37 \mathrm{a}$ & $3.94 \mathrm{a}$ \\
\hline
\end{tabular}

Within each cultivar, means with different letters are significantly different at $P \leq 0.05$ by Tukey's multiple range

TT, DI, and EI son el tratamiento testigo, 1/3 less, and 1/3 more irrigation, respectively

this location for 4 weeks before the thermal measurements were taken.

Each CMU on the green wall was considered as an independent fertigation circuit for the quantification of the input (irrigation) and output (drainage) volumes [29]. The fertigation for each CMU was supplied by one non-draining dripper with a flow rate of either 2,3 , or $4 \mathrm{~L} \mathrm{~h}^{-1}$, in correspondence with the treatments of experiment 1 . The treatments were vertically distributed as columns of CMUs in the middle of the green wall (Fig. 2b), and each column of CMUs was fertigated by one dripper with a flow rate of either 2,3 , or $4 \mathrm{~L} \mathrm{~h}^{-1}$.

\section{Thermometric measures}

The thermographic images were recorded in a similar fashion to those of experiment 1 . The thermographs were recorded (three replicates per wall type) when there was a continuous vegetative layer in which the CMUs could not be identified individually (Fig. 2c, f). An area larger than a group of three CMUs was measured for each treatment (Fig. 2b, e).

The rest of the parameters and methods were similar to those of experiment 1 .

\section{Results and discussion}

\section{Experiment 1}

Almost all of the growth parameters evaluated in the two crops were significantly affected by the irrigation volume (Table 1). The philodendron was affected in all of its growth parameters. The DI treatment led to a greater than $15 \%$ reduction in all parameters (except for stem height) compared to the CT. Conversely, the EI treatment did not yield a significant difference for the fresh and dry mass of the leaves; a lower percentage differences was observed for EI than for DI between the fresh and dry nass of the shoot.
Similar trends were also found in the anthurium, for which plants under DI had lower growth than those under CT or EI (except for the fresh nass of the root and the nass of the stem). However, the percentage differences in anthurium were significantly less compared to those of the philodendron (5 compared to $15 \%$ ).

The average transpiration of a leaf is determined by its temperature $[15,31]$. A thermograph of several pots (Figs. 1a, 3) with different irrigation treatments indicated a wide range of leaf temperatures. This wide temperature range was maintained even when measured on various leaves of the same plant under the same irrigation treatment (Fig. 1c). However, temperature is closely correlated with the state of available water from the pot when comparing equally developed leaves with the same spatial orientation toward incident radiation on the same plant $[12,13]$. The thermographs of the philodendron (Figs. 3, 4a) and the anthurium (Figs. 1b, 4b) recorded the lower temperature for the highest transpiration rate, when the irrigation treatment was most appropriate (CT vs. DI and CT vs. EI); this result is consistent with the observations of Fernández-Bregón et al. [12]. A higher growth reduction between DI and CT for the philodendron, compared to the difference between CT and EI, was also recorded by the thermograph; the temperature difference between DI and CT was approximately ten times greater than that recorded between CT and EI.

Under tightly controlled transpiration conditions, such as those employed in this experiment, the thermograph is closely correlated with the final vegetative growth results obtained during the crop cycle. Therefore, the thermograph can be a useful tool for the rapid, sensitive, easy, economic, and robust diagnosis of water and other plant stresses, especially before they manifest as crop damage.

This method was based on measuring only an appropriate leaf fraction under similar environmental conditions $[12,13]$; therefore, the technique avoided the errors in estimated temperature incurred when infrared thermography includes surfaces other than the desired area [3, 32]. 


\section{Experiment 2}

The thermographs of the sampled green walls are shown in Fig. 2. The thermograph sample areas d, e, and f (Figs. 2b and 2e) are approximately 1 square meter and correspond to DI, CT, and EI, respectively. The average temperatures recorded by the thermographs were similar to the trends shown for the same treatments in experiment 1 . However, the average differences in the temperatures between treatments compared to the control (DI vs. CT and EI vs. CT) were lower in this experiment, and the standard error was higher (Fig. 4). The following explanations are offered for the significant temperature variability recorded on these large vegetative cover areas:

1. Different transpiration rates were recorded for leaves of the same plant; in experiment 1, a temperature difference of up to $5 \%$ was recorded between leaves of the same plant under the same fertigation treatment (Fig. 1c);

2. Temperature variation also exists between the stem and the leaves [13];

3. The vegetative cover includes several species, as it is composed of the sum of the foliar surfaces of more than 75 plants (with 4-10 different species);

4. A temperature gradient existed in the vertical direction that is clearly reflected in the thermographs in Fig. 1.

Thermal images lose some of their power as a diagnostic tool when there is significant temperature variability in the same thermograph [3, 32]. However, images of a sufficiently large area with complete and continuous vegetative cover can detect the average temperature variation due to different irrigation treatments. Temperature variation can be clearly detected (Fig. 2d) by thermal images before withering is evident, even in a smaller area of $0.34 \mathrm{~m}^{2}$ (one CMU). As a result, thermometry can also be used on green walls to identify early water stress by non-destructive testing and remote sensing. Similar results have been reported for the identification of the uniformity of fertigation by infrared thermography under the soilless culture of pots [12] and for salinity stress [13].

We suggest that this methodology or other thermal analysis and calorimetry systems could be used by similar applications in crop protection and horticulture.

\section{Conclusions}

The results of this work suggest that thermography may be a useful diagnostic method for determining the adequate supply of fertigation to potted plants and aromatic and ornamental green walls.
Acknowledgements We would like to thank the Spanish government for its financial assistance through FEDER AGL-2010-18391.

Open Access This article is distributed under the terms of the Creative Commons Attribution License which permits any use, distribution, and reproduction in any medium, provided the original author(s) and the source are credited.

\section{References}

1. Garner DL, Underwood HB, Porter WF. Use of modern infrared thermography for wildlife population surveys. Environ Manage. 1995;19:233-8.

2. Grinzato E, Cadelano G, Bison P. Moisture map by IR thermography. J Mod Opt. 2010;57:1770-8.

3. Jones HG, Stoll M, Santos T, de Sousa C, Chaves MM, Grant OM. Use of infrared thermography for monitoring stomatal closure in the yield: application to grapevine. J Exp Bot. 2002;53: 2249-60.

4. Möller M, Alchanatis V, Cohen Y, Meron M, Tsipris J, Naor A, Ostrovsky V, Cohen S. Use of thermal and visible imagery for estimating crop water status of irrigated grapevine. J Exp Bot. 2007;58:827-38.

5. Inagaki MN, Nachit MM. Visual monitoring of water deficit stress using infra-red thermography in wheat. Sydney University Press. 2008. http://ses.library.usyd.edu.au/bitstream/2123/3452/1/ P181.pdf. Accessed 31 Oct 2012.

6. Krapez JC, Olioso A. A combination of temperature, vegetation indexes and albedo, as obtanined by airborne hyperspectral remote sensing, for the evaluation of soil moisture. Quant Infrared Thermogr J. 2011;8:187-200.

7. Prado AGS, Evangelista SM, SouzaDe JR, Matos JGS, Souza MAA, Oliveira DA, Airoldi C. Effect of the irrigation with residual wastewaters on microbial soil activity of the ornamental flowers (Dahlia pinnata) cultures monitored by isothermal calorimetry. J Therm Anal Calorim. 2011;106:431-6.

8. Wang F, Omasa K, Xing S, Dong Y. Thermographic analysis of leaf water and energy information of Japanese spindle and glossy privet trees in low temperature environment. Ecol Inform. 2013;16: 35-40.

9. Pearce RS, Fuller MP. Freezing of barley studied by infrared video thermography. Plant Physiol. 2001;125:227-40.

10. Glenn DM. Infrared and chlorophyll fluorescence imaging methods for stress evaluation. HortScience. 2012;47:697-8.

11. Antonucci F, Pallottino F, Costa CF, Rimatori V, Giorgi S, Papetti P, Menesatti P. Development of a rapid soil water content detection technique using active infrared thermal methods for infield applications. Sensors. 2011;11:10114-28.

12. Fernández-Bregón N, Valera D, Urrestarazu M. Uniformity of fertigation as diagnosed by infrared thermography under soilless culture. J Food Agric Environ. 2013;11:981-98.

13. Urrestarazu M. Infrared thermography used to diagnose the effects of salinity in a soilless culture. Quant Infrared Thermogr J. 2013;10:1-8.

14. Kümmerlen B, Dauwe S, Schmundt D, Schurr U. Thermography to measure water relations of plant leaves. In: Jähne B, editor. Handbook of computer vision and applications, vol. 3. London: Academic Press; 1999. p. 763-81.

15. Cox LM, Boersma L. Transpiration as a function of soil temperature and soil water stress. Plant Physiol. 1967;42:550-6.

16. Kumar A, Singh DP, Singh P. Influence of water stress on photosynthesis, transpiration, water use efficiency and yield of Brassica juncea L. Field Crops Res. 1994;37:95-101. 
17. Nilssona HE. Hand-held radiometry and IR-thermography of plant diseases in field plot experiments. Int J Remote Sens. 1991;12:545-57.

18. Chaerle L, Caeneghem WV, Messens E, Lamber H, van Montagu M, van der Straeten D. Presymptomatic visualization of plantvirus interactions by thermography. Nat Biotechnol. 1999;17: 813-6.

19. Chaerle L, de Boever F, van Montagu M, van der Straeten D. Thermographic visualization of cell death in tobacco and Arabidopsis. Plant, Cell Environ. 2001;24:15-25.

20. Chaerle L, Hagenbeek D, De Bruyne E, Valcke R, van der Straeten D. Thermal and chlorophyll-fluorescence imaging distinguish plant-pathogen interactions at an early stage. Plant Cell Physiol. 2004;45:887-96.

21. Oerke EC, Steiner U, Dehne HW, Lindenthal M. Thermal imaging of cucumber leaves affected by downy mildew and environmental conditions. J Exp Bot. 2006;57:2121-32.

22. Wang M, Ling N, Dong X, Zhu Y, Shen Q, Guo S. Thermographic visualization of leaf response in cucumber plants infected with the soil-borne pathogen Fusarium oxysporum f. sp. Cucumerinum. Plant Physiol Biochem. 2012;61:153-61.

23. James RA, Sirault XRR. Infrared thermography in plant phenotyping for salinity tolerance. Methods Mol Biol. 2012;913: 173-89.

24. Sonneveld C, Straver NB. Nutrient solution for vegetables and flowers grown in water or areas. Voedingspolossingen glastijnbouw. 1994;8:1-33.
25. Urrestarazu M. Tratado de cultivo sin suelo. Madrid: Ed. MundiPrensa; 2004. p. 914.

26. Urrestarazu M, Guillen C, Mazuela PC, Carrasco G. Wetting agent effect on physical properties of new and reused rockwool and coconut coir waste. Sci Hortic. 2008;116:104-8.

27. Little TM, Hills FG. Métodos estadísticos para la investigación en la agricultura [Statistical methods for agricultural research]. México: Ed. Trillas; 1987.

28. Statistical Graphics Corp. Statgraphics plus for Windows 5.0. Rockville: Statistical Graphics Corp; 2005.

29. Urrestarazu M, Burés S. Sustainable green walls in architecture. J Food Agric Environ. 2012;10:792-4.

30. Fernández-Bregón N, Urrestarazu M, Valera DL. Effects of a vertical greenery system on selected thermal and sound mitigation parameters for indoor building walls. J Food Agric Environ. 2012;10:1025-7.

31. Inoue Y, Kimball BA, Jackson RD, Pinter PJ, Reginato RJ. Remote estimation of leaf transpiration rate and based on infrared thermometry. Agric For Meteorol. 1990;51:21-33.

32. Moran MS, Clarke TR, Inoue Y, Vidal A. Estimating crop water deficit using the relation between surface-air temperature and spectral vegetation index. Remote Sens Environ. 1994;49: 246-63. 